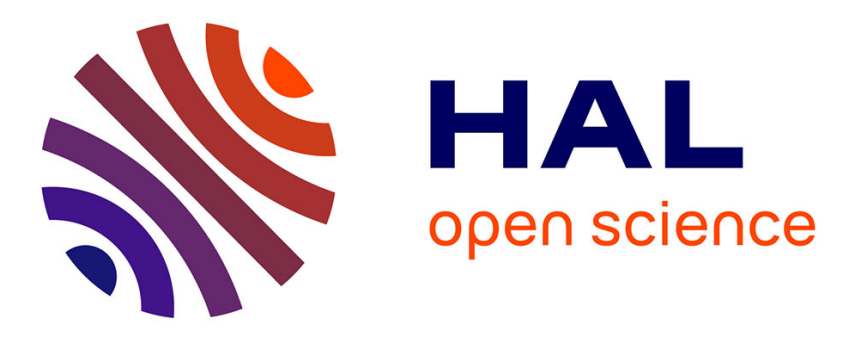

\title{
Characterization of natural and chemically modified kaolinite from Mako (Senegal) to remove lead from aqueous solutions
}

\author{
A. Mbaye, C. A. K. Diop, Jocelyne Miehe-Brendle, François Senocq, Francis \\ Maury
}

\section{To cite this version:}

A. Mbaye, C. A. K. Diop, Jocelyne Miehe-Brendle, François Senocq, Francis Maury. Characterization of natural and chemically modified kaolinite from Mako (Senegal) to remove lead from aqueous solutions. Clay Minerals, 2014, vol. 49 ( $\mathrm{n}^{\circ} 4$ ), pp. 527-539. 10.1180/claymin.2014.049.4.03 . hal01172299

\section{HAL Id: hal-01172299 \\ https://hal.science/hal-01172299}

Submitted on 7 Jul 2015

HAL is a multi-disciplinary open access archive for the deposit and dissemination of scientific research documents, whether they are published or not. The documents may come from teaching and research institutions in France or abroad, or from public or private research centers.
L'archive ouverte pluridisciplinaire HAL, est destinée au dépôt et à la diffusion de documents scientifiques de niveau recherche, publiés ou non, émanant des établissements d'enseignement et de recherche français ou étrangers, des laboratoires publics ou privés. 


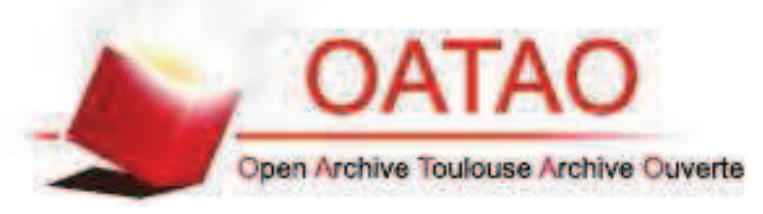

\section{Open Archive TOULOUSE Archive Ouverte (OATAO)}

OATAO is an open access repository that collects the work of Toulouse researchers and makes it freely available over the web where possible.

This is an author-deposited version published in : http://oatao.univ-toulouse.fr/ Eprints ID : 14105

To link to this article : doi: 10.1180/claymin.2014.049.4.03

URL : http://dx.doi.org/10.1180/claymin.2014.049.4.03

To cite this version : Mbaye, A. and Diop, C. A. K. and MieheBrendle, Jocelyne and Senocq, François and Maury, Francis Characterization of natural and chemically modified kaolinite from Mako (Senegal) to remove lead from aqueous solutions. (2014) Clay Minerals, vol. 49 ( $\mathrm{n}^{\circ}$ 4). pp. 527-539. ISSN 0009-8558

Any correspondance concerning this service should be sent to the repository administrator: staff-oatao@,listes-diff.inp-toulouse.fr 


\title{
Characterization of natural and chemically modified kaolinite from Mako (Senegal) to remove lead from aqueous solutions
}

\author{
A. MBAYE ${ }^{1}$, C. A. K. DIOP ${ }^{1, *}$, J. MIEHE-BRENDLE ${ }^{2}$, F. SENOCQ ${ }^{3}$ AND \\ F. MAURY ${ }^{3}$ \\ ${ }^{1}$ Laboratoire de Chimie Minérale et Analytique-Université Cheikh Anta Diop-Dakar-Sénégal, ${ }^{2}$ Equipe Matériaux \\ à Porosité Contrôlée, Institut de Science des Matériaux de Mulhouse (IS2M, UMR CNRS 7361. Université de Haute- \\ Alsace, Institut de Recherche Jean-Baptiste Donnet, 3 b rue Alfred Werner, 68093 Mulhouse cedex, France, and \\ ${ }^{3}$ CIRIMAT, ENSIACET, 4 allée E. Monso, BP 44362, 31030 Toulouse, cedex 4, France
}

\begin{abstract}
The chemical and sorption properties of clay minerals from the Mako area, Senegal, were investigated using FTIR spectroscopy, X-ray diffraction, scanning electron microscopy equipped with an X-ray energy dispersion spectrometer, thermal analysis and chemical analysis. The clay sample is essentially dominated by kaolinite and quartz as also shown by treatment with ethylene glycol and dimethylsulfoxide (DMSO). The clay fraction of this natural clay was organically modified by grafting with 3-aminopropyltriethoxysilane (APTES) in order to improve significantly its retention ability of heavy metals. The silane groups of the APTES reagent were partly grafted on the surface of platy kaolinite particles and the remaining ethoxy groups could be hydrolysed by aqueous treatment. The natural clay, its clay fraction and the organo-functionalized clay (with APTES) were investigated as adsorbents for the removal of $\mathrm{Pb}$ (II) from aqueous solutions. Evidence for an organic grafting has been demonstrated by comparing the spectroscopic characteristics of the natural clay and those of its chemically modified derivatives. The effects of different parameters (i.e. initial $\mathrm{Pb}$ (II) concentration and contact time) on the adsorption efficiency were studied. For an initial concentration of $10 \mathrm{mg} \mathrm{L}^{-1} \mathrm{~Pb}(\mathrm{II})$, the adsorption was maximized after 30 min contact time both for the raw material and its clay fraction and after 90 min for the APTES grafted clay. Although the maximum of sorption for the APTES grafted clay is reached with slower kinetics, this maximum amount of $\mathrm{Pb}(\mathrm{II})$ uptake at room temperature $\left(X_{\max }\right)$ is significantly higher since it is $0.99 \mathrm{mg} \mathrm{g}^{-1}$ for the raw clay, $1.46 \mathrm{mg} \mathrm{g}^{-1}$ for its clay fraction and $3.02 \mathrm{mg} \mathrm{g}^{-1}$ for the organically modified clay, i.e. three times greater than the raw clay.
\end{abstract}

KEYWORDS: kaolinite, functionalized clay, hybrid material, amino-compound, retention capacity, heavy metal removal, lead.

Kaolinite $\left[\mathrm{Al}_{4}\left(\mathrm{Si}_{4} \mathrm{O}_{10}\right)(\mathrm{OH})_{8}\right]$ is an important clay mineral having widespread applications in ceramics, in the manufacture of paper (as coating pigment and filler), ink, paintings (as extender) and additives for rubber and polymers. The most important applica-

*E-mail: cakdiop@ucad.sn tions of kaolinite are in papers on the ceramic, cosmetics and pharmaceutical industries (Harvey \& Murray, 1997; Murray, 2000). The sorption properties of kaolinite (Sari et al., 2007; Wang et al., 2011) lead to applications in the fields of heavy metal and radionucleides retention (Gupta \& Bhattacharyya, 2008; Jiang et al., 2009). The intercalation of metallic cations or organic species is very difficult to achieve (Theng, 1974) because 
of its very low cation exchange capacity (CEC). Adsorption generally occurs on the external crystal surface of kaolinite while the CEC results from protonation/deprotonation and isomorphous substitution of $\mathrm{Al}$ for $\mathrm{Si}$ in the tetrahedral sheets (Grim, 1953; Chi \& Eggleton, 1999).

Artisanal activity of lead recycling from used batteries causes many environmental pollution problems in Senegal. Such activity causes lead (but also arsenic and antimony) contamination of both ground and surface water used for drinking and crop irrigation. In addition to battery recycling activity, paint manufacturing in Senegal also contributes to the increase of lead concentration in the environment. For these reasons, Senegal and most part of Africa will face in the near future a grave problem of heavy metal pollution and the implementation of solutions is mandatory.

Several works dealing with sorption of heavy metals onto clay minerals, especially montmorillonite, have been reported (Mercier \& Detellier 1995; Celis et al., 2000; Lagadic et al., 2001; Vengris et al., 2001; Yariv, 2002). The sorption capacity of kaolinite and of clay minerals in general can be enhanced by modifying their surfaces with organic ligands that introduce Lewis base functionalities to the materials (Lothenbach et al., 1997; Malakul et al., 1998). The development of hybrid organicinorganic matrices has attracted great interest owing to their growing applications in several areas such as nanotechnology, environmental engineering and clay sciences (Dennis et al., 2001; Beall, 2003; Gómez \& Sanchez, 2004; Groisman et al., 2004; Paul \& Robeson, 2008). The most important methods used to prepare organo-clays are (i) intercalation reactions (via the soft guest displacement method or impregnation of organic moieties), (ii) covalent grafting, for instance with organosilane (Tunney \& Detellier, 1993; Vansant et al., 1995; Tunney \& Detellier, 1997; Nakagaki et al., 2004; He et al., 2005; Shanmugharaj et al., 2006; Tonle et al., 2007; de Faria et al., 2010; Shu-qin et al., 2012) or alcohols such as n-alkanols, diols, longchain glycol mono-ethers, etc. (Letaief \& Detellier, 2008) and (iii) replacement of the exchangeable cations by organic molecules (Yariv, 2002; Xi et al., 2007). This last method is widely used for smectites, but leads generally to a small organic content when it is applied to kaolinite due to its very low CEC value.

In the course of a general program aimed at the study of natural clay minerals and their applications
(Bouna et al., 2010, 2011; Mbaye et al., 2012), this paper reports the characteristics and properties of a natural clay from the Mako area in the southeastern part of Senegal. The clay fraction and organically modified derivatives were also investigated. Instrumental methods such as FTIR spectroscopy, X-ray diffraction, scanning electron microscopy equipped with an X-ray energy dispersion spectrometer, thermal analysis and elemental analysis, performed on the raw clays or its clay fraction and their DMSO or ethylene-glycol intercalates show that the natural clay mineral used in this work consists mainly of kaolinite and that the most important impurity is quartz. In order to enhance the adsorption performance of this natural clay, currently used as raw material in pottery and building, the clay fraction was isolated and grafted with 3-aminopropyltriethoxysilane (APTES). The clay samples and the APTES grafted organo-hybrid material were tested as sorbents for the uptake of heavy metal such as $\mathrm{Pb}$ (II) from aqueous solutions. The adsorption characteristics of the natural and the APTES modified clays were investigated as a function of the contact time and the amount of initial $\mathrm{Pb}$ (II) and the sorbent in the aqueous solution with the objective of optimizing the removal process.

\section{EXPERIMENTAL}

Origin of the clay and geological setting of the sampling area

The clay samples were collected from the Mako area $\left(12^{\circ} 52^{\prime} 0 \mathrm{~N}\right.$ and $\left.12^{\circ} 20^{\prime} 60 \mathrm{~W}\right)$. Mako is part of the Kédougou-Kéniéba inlier (KKI) in the south eastern part of Senegal (Fig. 1). The Gambia River and the Senegal River (Falémé) cross this region. The KKI (Fig. 1) is the western most exposed part of the Palaeoproterozoic Birrimian terrain and is commonly divided into two supergoups, Mako and Diale-Daléma. The Mako supergroup comprises associations of volcanic rocks (basalts, basaltic andesite, andesite and rhyodacite) and subvolcanic (microdiorites and microgabbros), in intercalation with sets of volcano-sedimentary rocks (tuffs, cinerites and greywackes) and sedimentary rocks (limestone, sandstone and mudstone). The geology of the KKI has been the subject of several geological and map studies (Barruseau et al., 2009; Sarr et al., 2011). The raw clay from Mako was labelled ArgB and its clay fraction $(<2 \mu \mathrm{m}) \mathrm{K}$-Mako. This latter 


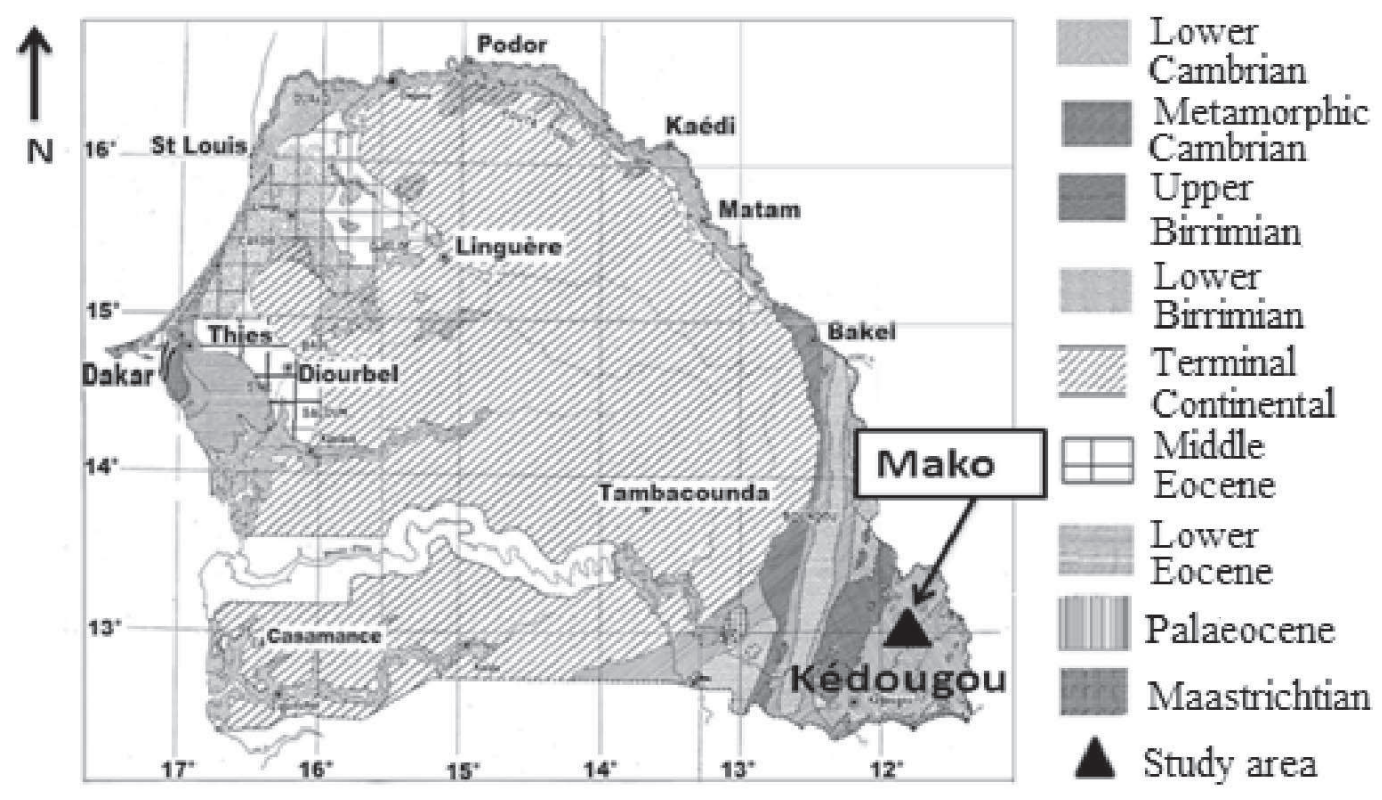

FIG. 1. Geological structure of the studied area.

material was extracted using standard sedimentation procedures (Holtzapfell, 1985).

\section{Chemical reagents}

Lead nitrate $\left(\mathrm{PbNO}_{3}, \mathrm{ACROS}\right)$, aminopropyltriethoxysilane (APTES, ACROS) dimethylsulfoxide (DMSO, Fischer Scientific) and toluene were used without further purification.

\section{Characterization methods}

The chemical composition of the clay samples was determined by inductively coupled plasmaoptical emission spectrometry using an ICP-OES Iris Advantage ERS instrument equipped with a radially viewed torch (Thermo Scientific). Samples were powdered and fused in a Pt crucible with ultra-pure $\mathrm{LiBO}_{2}$. After cooling at room temperature, the fused clay was dissolved in $1 \mathrm{~N}^{\mathrm{HNO}_{3}}$. XRD patterns of the kaolinite and modified organokaolinite were obtained on a Philips PW 1800 diffractometer using $\mathrm{Cu}-K \alpha_{1}$ radiation $(\lambda=$ $0.15406 \mathrm{~nm}$ ) and a scanning range $1-70^{\circ} 2 \theta$ with a step size of $0.02 \%$. A LEO435VP scanning electron microscope (SEM) equipped with an X-ray energy dispersion spectrometer (EDS) was used to characterize the morphology of clay particles and to perform point elemental analysis. Infrared transmission spectra (IR) were recorded by using $\mathrm{KBr}$ pellets on a Bruker IFS 66 IR spectrometer with a DTGS detector and analysed with OPUS software. The number of scans was fixed at 32 with a resolution of $4 \mathrm{~cm}^{-1}$. Thermal gravimetric (TG) and derivative thermal gravimetric (DTG) analyses of kaolinite and organo-kaolinite were performed with a TG-DSC apparatus (Setaram TG-DSC 111) under air at heating rate of $5^{\circ} \mathrm{C} \mathrm{min}^{-1}$.

\section{Preparation of the organo-clays}

The intercalation of DMSO into the kaolinite interlayer and the purification was performed following Shu-qin Yang et al. (2012). $2.5 \mathrm{~g}$ of kaolinite was added to a flask containing $15 \mathrm{~mL}$ of DMSO. The mixture was stirred and refluxed for $12 \mathrm{~h}$ at $150^{\circ} \mathrm{C}$ followed by aging at room temperature for $12 \mathrm{~h}$. The solid material was then separated by centrifugation and washed several times with isopropanol to eliminate the non-reacting DMSO. The obtained solid was dried at $60^{\circ} \mathrm{C}$ in an oven. $1.5 \mathrm{~g}$ of the raw kaolinite (ArgB) or its clay fraction (K-Mako) was dispersed in $90 \mathrm{~mL}$ of toluene under magnetic stirring. Then $7.5 \mathrm{~mL}$ of 
APTES was added dropwise. The mixture was stirred for $24 \mathrm{~h}$ under reflux and centrifuged and the solid was dried $70^{\circ} \mathrm{C}$ for $24 \mathrm{~h}$. The raw material and the clay fraction grafted with APTES were labelled ArgB-APTES and K-Mako-APTES respectively. The silanisation grafting reaction is schematically represented in Fig. 2.

\section{Sorption and intercalation of $\mathrm{Pb}(\mathrm{II})$}

Standard solutions of the desired $\mathrm{Pb}(\mathrm{II})$ concentration were prepared by diluting a stock solution of $\mathrm{Pb}$ (II) with concentration of $1 \mathrm{~g} \mathrm{~L}^{-1}$. The stock solution was obtained by dissolving $\mathrm{Pb}\left(\mathrm{NO}_{3}\right)$ in distilled water. $0.1 \mathrm{~g}$ of clay (ArgB, K-Mako or K-Mako-APTES) was added in a beaker containing $10 \mathrm{~mL}$ of aqueous solution of $\mathrm{Pb}(\mathrm{II})$, the initial concentration of the $\mathrm{Pb}(\mathrm{II})$ solution varying from 5 to $60 \mathrm{mg} \mathrm{L}^{-1}$. The mixture was stirred for 0-90 min at ambient temperature and filtered. The $\mathrm{pH}$ of the solution was adjusted to 6.5 using either $\mathrm{HCl}$ or $\mathrm{NaOH}$ solutions. The concentration of $\mathrm{Pb}$ (II) in the supernatant was determined by ICP-OES and the absorbed quantities were calculated by subtracting the concentration of $\mathrm{Pb}$ (II) in the supernatant liquid from the initial concentration.

\section{RESULTS AND DISCUSSION}

\section{Morphological characterization}

The morphology of the clay fraction and a typical EDS spectrum are shown in Figs 3 and 4, respectively. The SEM micrographs show a relatively homogeneous morphology consisting of small, sometimes hexagonal, platelets of different sizes, typical of kaolinite (Fig. 3a). The characteristic randomly oriented platelets of kaolinite are stacked on one another to form large grains of a few micrometers size (Fig. 3b). The platelets and the grains are partially coated with sub-micrometric particles and debris that could originate from broken plates or heterogeneous phases.

The EDS spectrum of the kaolin sample shows the presence of $\mathrm{Si}$ and $\mathrm{Al}$ as main elements and $\mathrm{Ti}$, $\mathrm{Fe}, \mathrm{Ca}, \mathrm{Mg}$ and $\mathrm{Na}$ as minor ones (Fig. 4). The intense $\mathrm{Si}$ peak could be ascribed to clay minerals and possibly free $\mathrm{SiO}_{2}$ (vide infra) whereas $\mathrm{Ti}$ probably results from anatase or rutile impurities. $\mathrm{Ca}$ and $\mathrm{Mg}$ are likely to be due to carbonates such as dolomite and/or calcite, while $\mathrm{Fe}$ is probably due to the goethite as evidenced by XRD (see below).

\section{$X$-ray diffraction analysis}

XRD patterns of the natural clay (ArgB), its clay fraction (K-Mako) and the organically modified clays are presented in Fig. 5. The XRD pattern of the raw clay (Fig. 5a) shows intense reflections due to quartz (Q), which consequently appears to be the most abundant impurity. The reflections observed at $7.15,3.57$ and $2.3 \AA$ indicate the presence of a second phase identified as kaolinite (Fig. 5b). This attribution is supported by the disappearance of these XRD peaks after heating the sample at $490^{\circ} \mathrm{C}$ (data not shown; Holtzapffel, 1985). Further

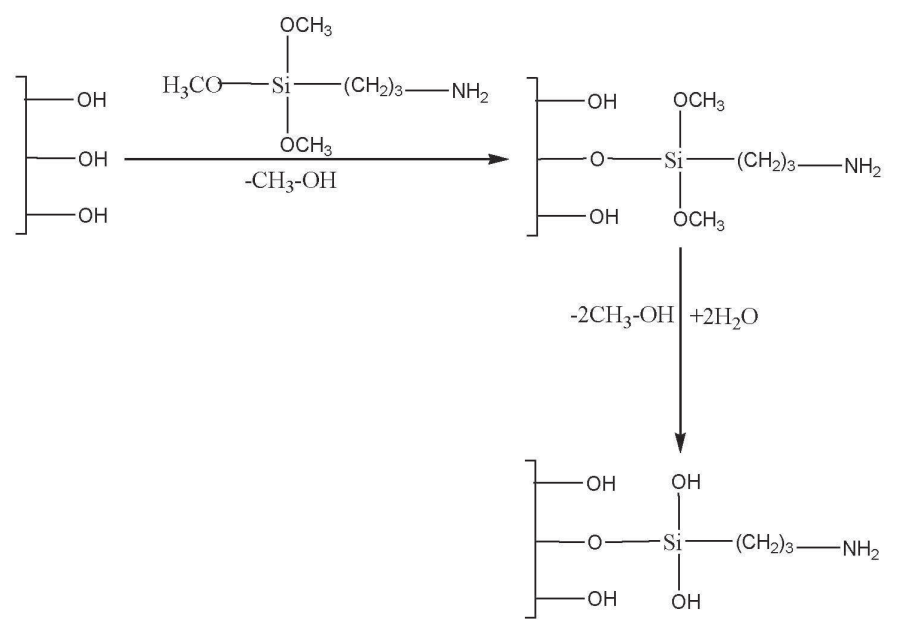

FIG. 2. Silanization grafting reaction of clay. 


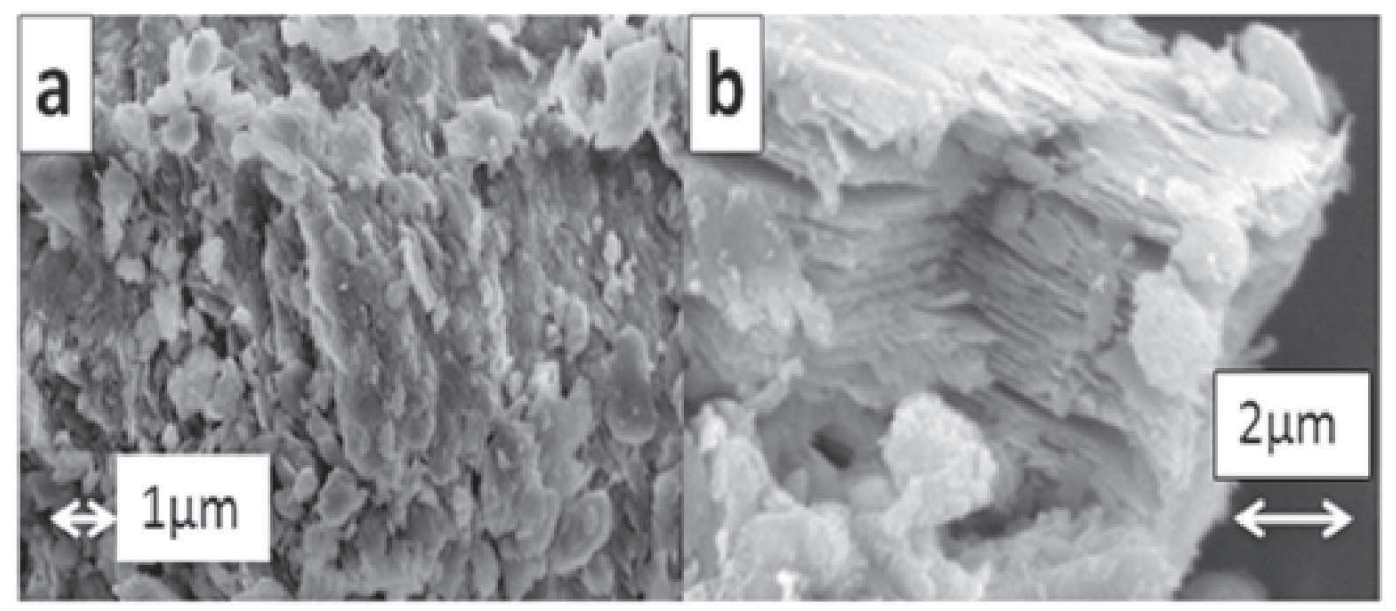

FIG. 3. SEM micrographs of the clay fraction (K-Mako sample) at different magnifications.

treatments with ethylene glycol and DMSO also support this assertion. The treatment with ethylene glycol (K-Mako-gly) did not change significantly the XRD pattern of the clay fraction, except for a slight broadening of the (001) reflection of kaolinite (Fig. 5b). By contrast this (001) reflection was strongly affected by the intercalation of DMSO since this peak is shifted from 7.15 to $11.1 \AA$. The peaks at $\sim 10$ and $5.1 \AA$ are due to illite, whereas goethite was also identified. As a result, the raw clay and the separated clay fraction is found to consist of a mixture of kaolinite and quartz associated with traces of illite and goethite. The clay fraction grafted with APTES did not show significant change of the basal spacing as the (001) reflection of kaolinite remains unaffected (Fig. 5b).
However a broadening of this reflection was recorded, which could be attributed to a slight decrease of the particle size and to the APTES grafting on the outer surfaces of kaolinite (Nakagaki et al., 2004).

\section{Elemental analysis}

The chemical compositions of the raw clay $(\mathrm{ArgB})$ and its clay fraction (K-Mako) are reported in Table 1. The results reveal that the raw clay essentially consists of $\mathrm{Si}$ and $\mathrm{Al}$. The amount of iron oxide is also noticeable while the contents of alkalis and alkaline-earth elements are low. The significant iron oxide content explains the light rusty colour of the raw clay sample. The

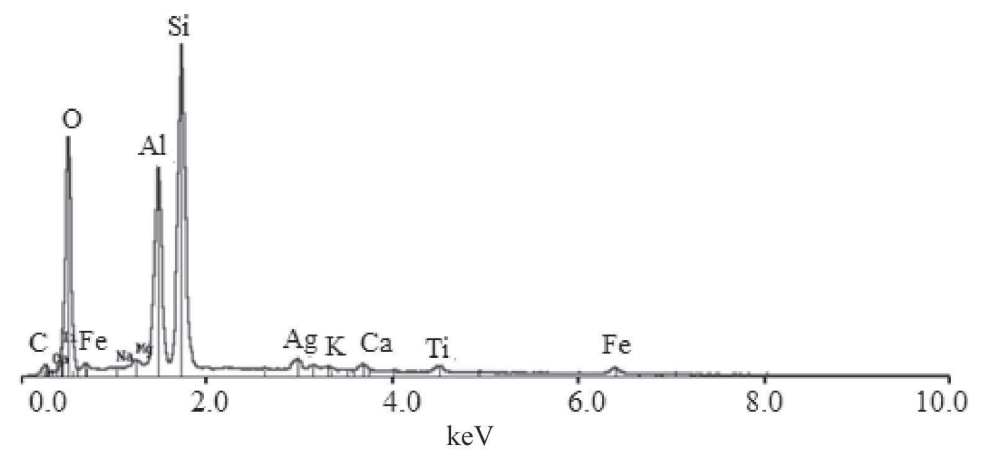

FIG. 4. EDS spectra of K-Mako sample. The silver detected at $3 \mathrm{keV}$ originates from the conductive adhesive used to fix the powder on the sample holder. 


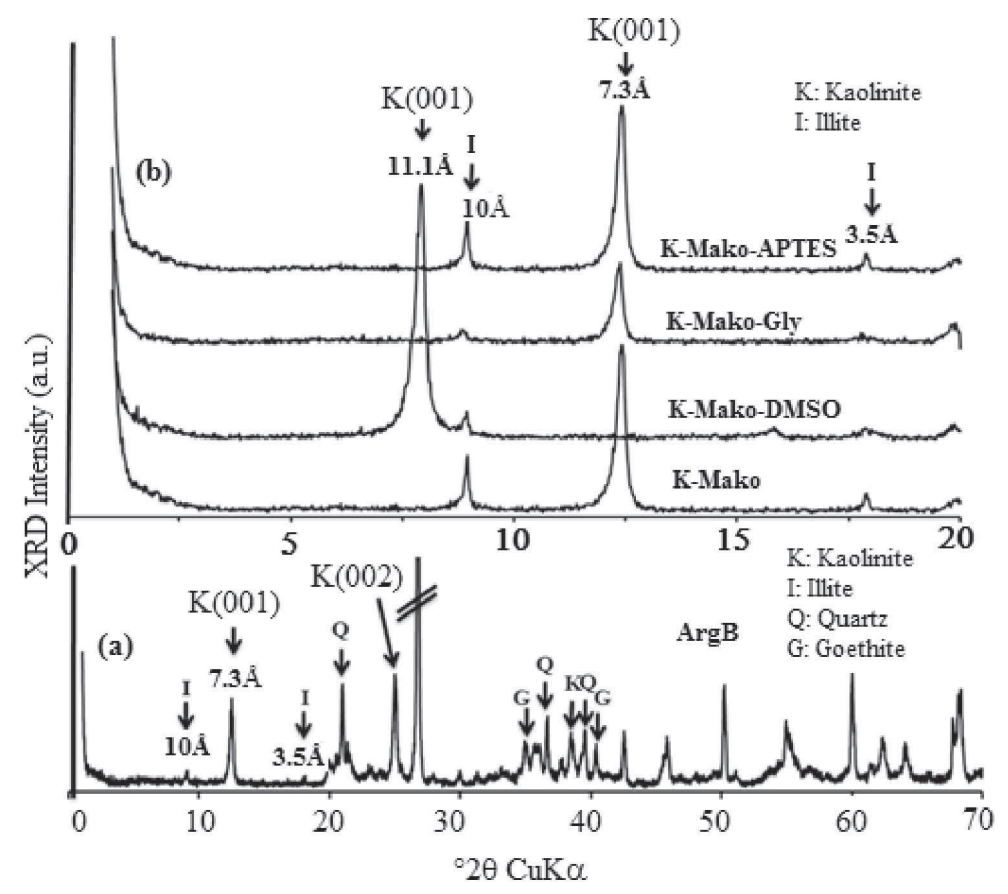

FIG. 5. XRD patterns of (a) the raw clay $\operatorname{ArgB}$ and (b) the clay fraction (K-Mako), the organically modified samples (K-Mako-DMSO, K-Mako-Gly) and grafted samples (K-Mako-APTES).

composition of the fine clay fraction is different from that of the raw clay, characterized by a significant increase of $\mathrm{Al}$ and a concomitant decrease of $\mathrm{Si}$.

\section{Fourier Transform Infrared spectroscopy}

The infrared absorption spectra of the clay fraction (K-Mako) and the organo-clays (K-MakoDMSO and K-Mako-APTES) are shown in Fig. 6. The band assignment has been made by comparison with the data reported for kaolinite and organokaolinite (Farmer \& Russell, 1964; Ledoux \& White, 1964; Farmer, 1974; Beutelspacher, 1976;
Petit \& Decarreau, 1990; Petit et al., 1995; Franco et al., 2004). The bands located at 3696, 3669 and $3652 \mathrm{~cm}^{-1}$ on the K-Mako IR spectrum are the typical signature of inner-surface hydroxyls of kaolinite and the one at $3619 \mathrm{~cm}^{-1}$ is attributed to the stretching frequency of the internal hydroxyl groups (Famer \& Russell, 1964). The broad bands around 3400 and $1620 \mathrm{~cm}^{-1}$ are due to the adsorbed water. The intense bands around $1030 \mathrm{~cm}^{-1}$ with two with shoulders around 1100 and $1005 \mathrm{~cm}^{-1}$ in the IR spectra of the K-Mako specimen correspond to the stretching vibrations of the $\mathrm{Si}-\mathrm{O}-\mathrm{Si}$ group. The band at $694 \mathrm{~cm}^{-1}$ is due the bending mode of the same group. The band at

TABLE 1. Elemental analysis of the clay fraction of Mako (wt.\%).

\begin{tabular}{lcccccccccccr}
\hline & $\mathrm{SiO}_{2}$ & $\mathrm{Al}_{2} \mathrm{O}_{3}$ & $\mathrm{Fe}_{2} \mathrm{O}_{3}$ & $\mathrm{MnO}$ & $\mathrm{MgO}$ & $\mathrm{CaO}$ & $\mathrm{Na}_{2} \mathrm{O}$ & $\mathrm{K}_{2} \mathrm{O}$ & $\mathrm{TiO}_{2}$ & $\mathrm{P}_{2} \mathrm{O}_{5}$ & LOI & Total \\
\hline ArgB & 79.03 & 6.90 & 3.33 & 0.01 & 0.67 & 0.56 & 0.13 & 0.15 & 0.61 & 0.13 & 7.65 & 99.17 \\
K-Mako & 46.87 & 24.61 & 4.62 & 0.02 & 0.85 & 1.06 & 0.06 & 0.38 & 1.25 & 0.10 & 20.60 & 100.42
\end{tabular}




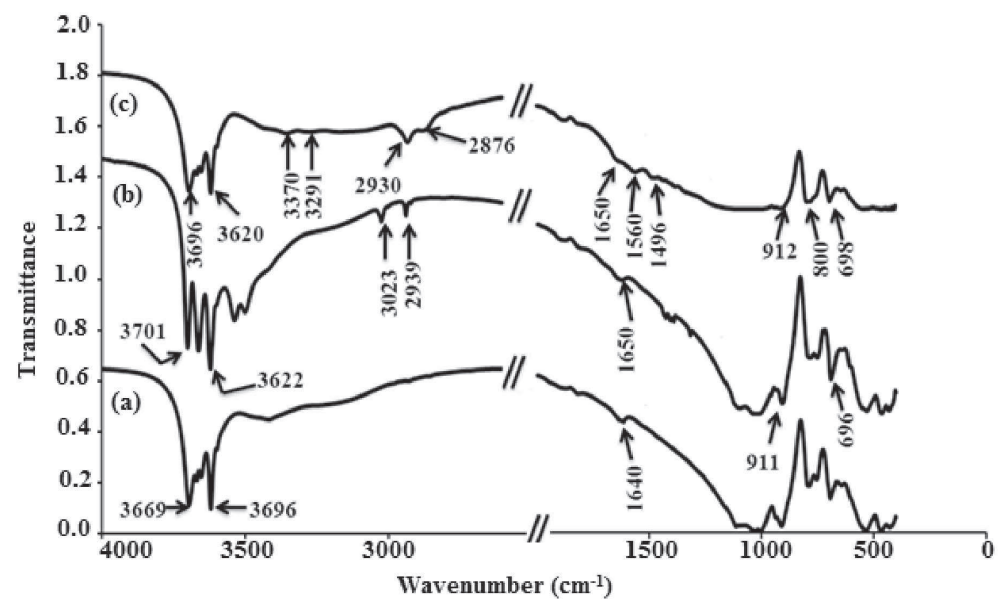

FIG. 6. FTIR spectra of samples (a) K-Mako, (b) K-Mako-DMSO, (c) K-Mako-APTES showing the presence of $v(\mathrm{C}-\mathrm{H})$ at $\sim 2900 \mathrm{~cm}^{-1}$ in modified samples.

$910 \mathrm{~cm}^{-1}$, with a shoulder at $930 \mathrm{~cm}^{-1}$, and the one at $540 \mathrm{~cm}^{-1}$ are related to $\mathrm{Al}-\mathrm{OH}$ and $\mathrm{Al}(\mathrm{VI})-\mathrm{O}-\mathrm{Si}$ bending vibrations, respectively (Van der Marel \& Beutelspacher, 1976; Petit \& Decarreau, 1990; Wilson, 1994; Saikia et al., 2003). The presence of quartz in all the samples was confirmed by the doublet around at 800 and $775 \mathrm{~cm}^{-1}$ (Vizcayno et al., 2010).

The IR spectra can commonly provide useful information on the surface modification of the kaolinite. In the case of intercalated DMSO organoclay the bands due to the inner surface hydroxyls stretching are totally modified; these bands are indeed influenced by interlayer modification. The bands at 3541 and $3505 \mathrm{~cm}^{-1}$ are due to the interaction between the DMSO and the inner surface OH groups (Frost et al., 1998; Shu-qin et al., 2012). The bands at 3027 and $2939 \mathrm{~cm}^{-1}$ are assigned to the $\mathrm{C}-\mathrm{H}$ stretching vibrations of aliphatic $\mathrm{CH}_{2}$ and $\mathrm{CH}_{3}$ groups. These additional bands in comparison with the non intercalated kaolinite are consistent with the insertion of organic functionalities onto the clay mineral.

The four bands between $1600-1700 \mathrm{~cm}^{-1}$ due to the internal and inner-surface hydroxyl groups, in the IR spectrum of K-Mako-APTES, did not undergo significant changes (Fig. 6). Therefore the new bands appearing at 2930 and $2876 \mathrm{~cm}^{-1}$ are assigned to the stretching vibrations of the aliphatic $\mathrm{CH}_{3}$ and $\mathrm{CH}_{2}$ groups. The bands at 3291 and $1560 \mathrm{~cm}^{-1}$ are due $v \mathrm{~N}-\mathrm{H}$ and $\delta \mathrm{N}-\mathrm{H}$.

The FTIR spectra of the K-Mako sample and the organo-clays show the characteristic bands of the host materials, mainly composed of kaolinite and those of the intercalated substances (Stathi et al., 2007).

\section{Thermal analysis}

The TG and DTG curves of the K-Mako sample are illustrated in Fig. 7a. The broad intense endothermic peak at $506^{\circ} \mathrm{C}$ corresponds to the dehydroxylation of kaolinite. The peaks at 23, 152 and $260^{\circ} \mathrm{C}$ are due to the removal of adsorbed water molecules. The peak at $335^{\circ} \mathrm{C}$ can be attributed to the transformation of the goethite $(\mathrm{FeOOH})$ into $\alpha-\mathrm{Fe}_{2} \mathrm{O}_{3}$ as was previously revealed by the XRD pattern (Fig. 5). In the case of the modified K-Mako-DMSO and K-Mako-APTES samples prepared from the clay fraction (Fig. $7 b, c$ ), the TG curves show several mass losses in the temperature range $400-700^{\circ} \mathrm{C}$. The non functionalized clay K-Mako displays dehydroxylation of the aluminol groups at $\sim 506^{\circ} \mathrm{C}$ and is indicated by a single event while two or three events have been observed in the case of the modified clays. The characteristic temperatures at which the rate of mass-change is maximum were observed at 458 , 551 and $688^{\circ} \mathrm{C}$ for the K-Mako-DMSO and at 620 and $667^{\circ} \mathrm{C}$ for K-Mako-APTES samples. This provides evidence for the presence of different types of hydroxyl groups in the organo-clays. The thermal event at $\sim 688^{\circ} \mathrm{C}$ in the two modified samples could arise from $\mathrm{OH}$ interacting via strong hydrogen bonds with the guest reagent (APTES or DMSO). In the organo-clays the 

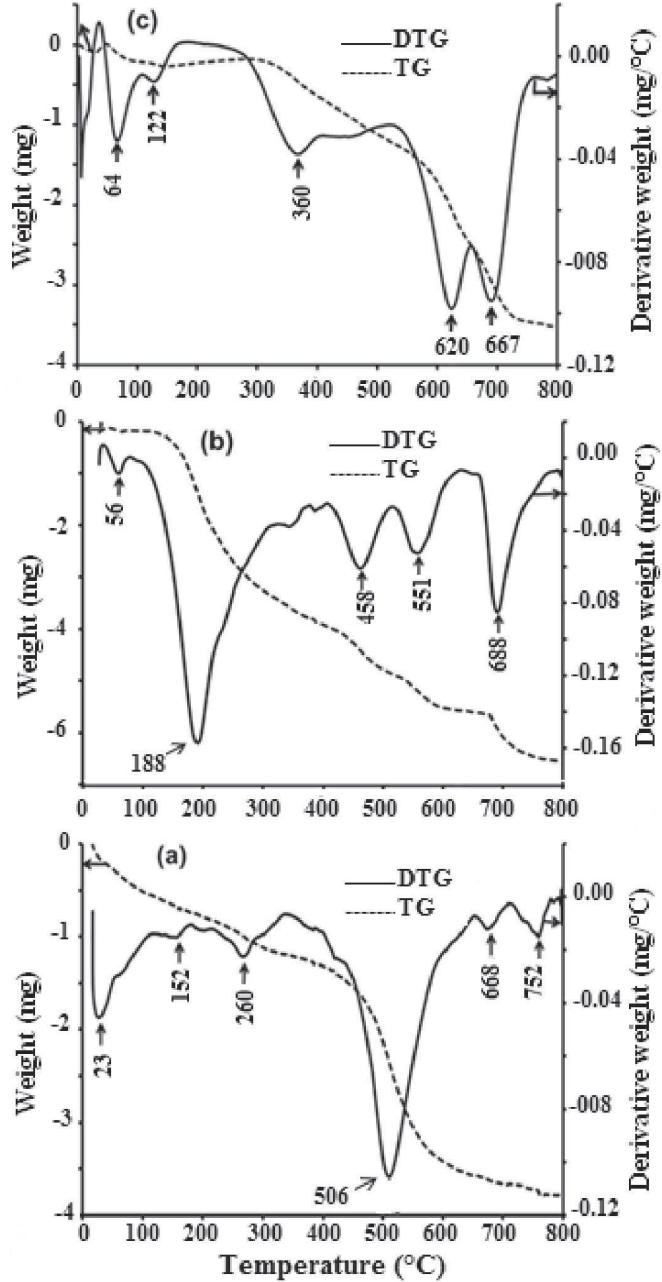

Fig. 7. TG and DTG curves of (a) K-Mako, (b) K-Mako-DMSO and (c) K-Mako-APTES samples.

dehydration occurs in the $50-150^{\circ} \mathrm{C}$ range, with little weight loss compared to the natural clay. The weight loss between 150 and $400^{\circ} \mathrm{C}$ is attributed to the presence of an organic radical in the clay as noted in some intercalated kaolinites (Tonle et al., 2007; Shu-qin et al., 2012).

\section{Sorption of $\mathrm{Pb}(\mathrm{II})$}

Clay minerals may form complexes with metals via the silanol and aluminol groups at their edges (Erdemoglu et al., 2004). Silanisation reactions were conducted to incorporate amino ligands on kaolinite and to enhance its complexation capacity (Fig. 2). In order to optimize the sorption capacity of clays and organo-clays towards heavy metal cations, the effect of contact time and initial concentration of $\mathrm{Pb}$ (II) on the adsorption of $\mathrm{Pb}$ (II) ions into clays was studied. Adsorption of $\mathrm{Pb}(\mathrm{II})$ onto various materials has been systematically studied in the past and shown to depend on the pH (Pagenkopf, 1978; Ikhsan et al., 1999; Srivasta et al., 2005; Oyenedel-Craver \& Smith, 2006). Erdemoglu et al. (2004) have shown that the $\mathrm{Pb}(\mathrm{II})$ adsorption was not measurable for $\mathrm{pH}$ values between 2 and 3, and that it increased considerably to reach a maximum at $\mathrm{pH} 6.5$ before decreasing at pH 6.5-10. Polymeric hydroxo complexes of lead, for instance $\mathrm{Pb}(\mathrm{OH})_{3}^{-}, \quad \mathrm{Pb}(\mathrm{OH})_{2}, \mathrm{~Pb}_{3}(\mathrm{OH})_{4}^{2+}$, $\mathrm{Pb}_{4}(\mathrm{OH})_{4}^{4+}, \mathrm{Pb}_{6}(\mathrm{OH})_{8}^{4+}$, are formed in this last $\mathrm{pH}$ range. The removal of $\mathrm{Pb}(\mathrm{II})$ species up to $\mathrm{pH} 6$ is essentially due to adsorption and hydroxide precipitation processes (Huang \& Fuerstenau, 2001). The $\mathrm{pH}$ was fixed at 6.5 following Erdemoglu et al. (2004), who suggested that the adsorption is largely predominant on the hydroxide precipitation at $\mathrm{pH} \sim 6.5$. In addition, the precipitation of the first lead hydroxide $\mathrm{Pb}(\mathrm{OH})^{+}$complex with stability constant $\log \mathrm{K}=5.88$ ) occurs between pH 6.5 and 7.

Figure 8 shows the kinetic adsorption curves obtained with a constant amount of adsorbent as a function of the contact time. The time-dependent behaviour of $\mathrm{Pb}(\mathrm{II})$ uptake was examined by varying the contact time between the $\mathrm{Pb}$ (II) ions and the clay samples (ArgB, K-Mako, K-MakoAPTES) between 10 and $160 \mathrm{~min}$ (Fig. 8). The amount of $\mathrm{Pb}(\mathrm{II})$ ion adsorbed on $\mathrm{ArgB}$ and K-Mako-APTES clays increased rapidly for contact times of $0-30 \mathrm{~min}$ and then remained almost constant, whereas in K-Mako it continued increasing slightly up to $90 \mathrm{~min}$ before reaching a plateau corresponding to equilibrium. Therefore, a $60 \mathrm{~min}$ contact time was found appropriate for maximum adsorption and it was used in all subsequent experiments. The amount of $\mathrm{Pb}(\mathrm{II})$ uptake clearly increases in the order: $\operatorname{ArgB}(60 \%)$ $<$ K-Mako $(70 \%)<$ K-Mako-APTES $(90 \%)$.

Figure 9 shows the influence of the initial concentration on the adsorption of $\mathrm{Pb}$ (II) from the aqueous solution for a contact time of $60 \mathrm{~min}$. The retention rate $(R)$ was calculated from the following equation:

$$
R(\%)=\left[\left(C_{0}-C_{\mathrm{e}}\right) / C_{0}\right] \times 100
$$




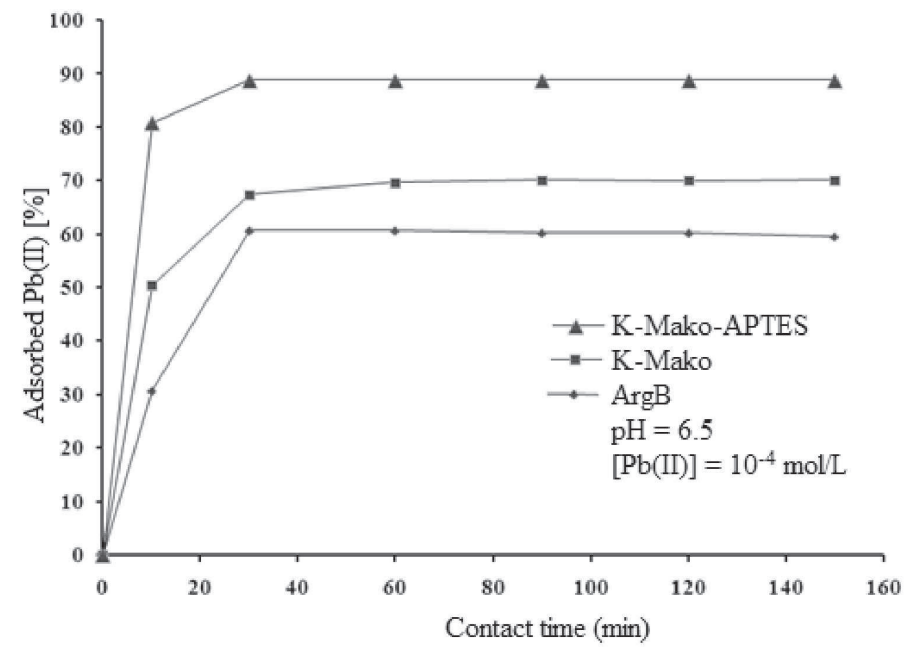

FIG. 8. Effect of contact time on the adsorption of $\mathrm{Pb}(\mathrm{II})$ ions on samples ArgB, K-Mako and K-Mako-APTES for an initial $\mathrm{Pb}(\mathrm{II})$ concentration of $10 \mathrm{mg} \mathrm{L}^{-1}$.

where $C_{0}$ and $C_{\mathrm{e}}$ are the initial and final $\mathrm{Pb}(\mathrm{II})$ concentration $\left(\mathrm{mg} \mathrm{L}^{-1}\right)$

The adsorption reaches a maximum value for approximately $10 \mathrm{mg} \mathrm{L}^{-1}$, and then it decreases very slightly (Fig. 9). For this $\mathrm{Pb}$ (II) concentration the KMako-APTES sample adsorbs about $88 \%$, the fine fraction K-Mako $65 \%$ and the raw clay ArgB sample about $59 \%$. For higher initial concentrations the trend remains the same since the adsorption decreases very slightly with the same slope for each sample.

The experimental adsorption results were described by the Langmuir adsorption model (Do, 1998) based on equation 2:

$$
q e=\frac{X_{\max } b C_{\mathrm{e}}}{1+b C_{\mathrm{e}}}
$$

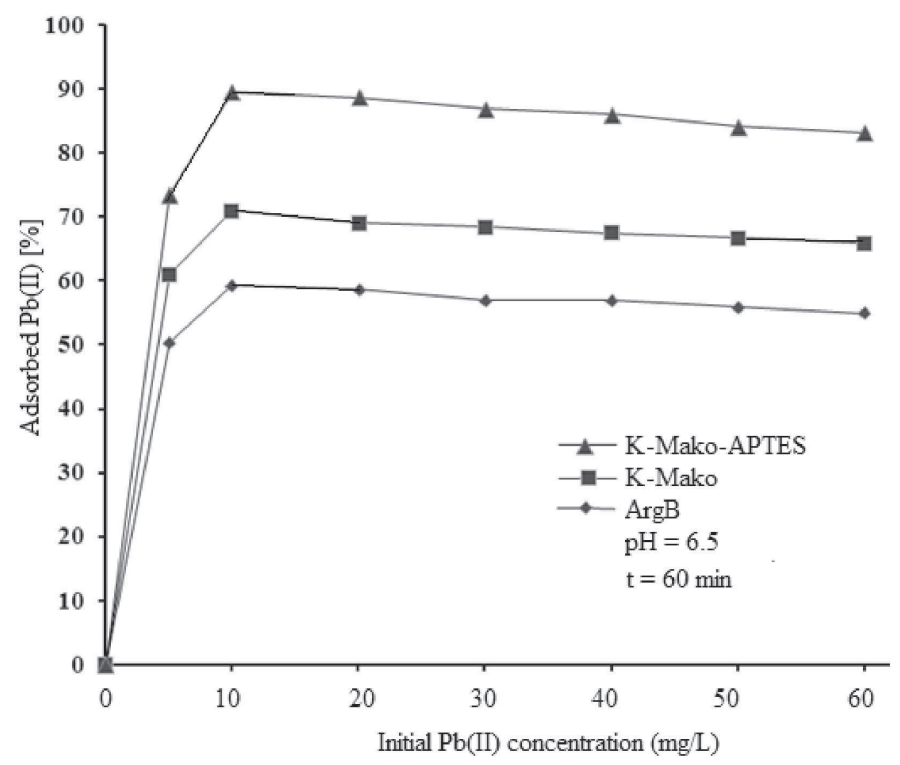

FIG. 9. Effect of initial $\mathrm{Pb}(\mathrm{II})$ concentration of the aqueous solution on the adsorption of $\mathrm{Pb}$ (II) ions on samples ArgB, K-Mako and K-Mako-APTES for contact time of $60 \mathrm{~min}$. 


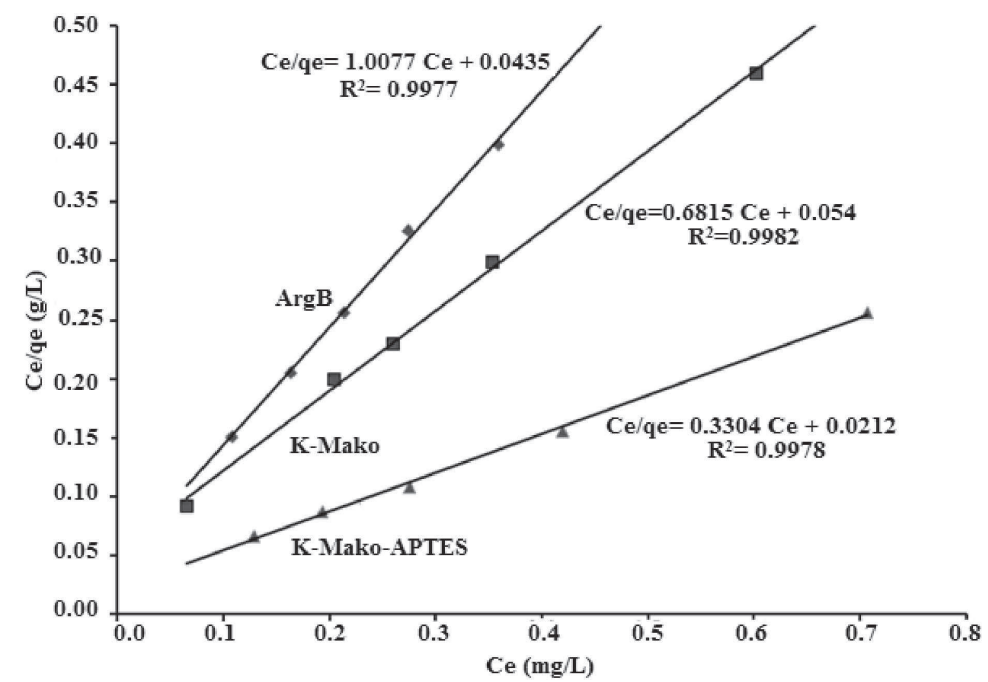

FIG. 10. Langmuir adsorption isotherms for the removal of $\mathrm{Pb}(\mathrm{II})$ from aqueous solutions using samples ArgB, $\mathrm{K}$ Mako and K-Mako-APTES.

or its linear form:

$$
\frac{C_{\mathrm{e}}}{q e}=\frac{1}{X_{\max } b}+\frac{C_{\mathrm{e}}}{X_{\max }}
$$

where qe is the amount of $\mathrm{Pb}(\mathrm{II})$ adsorbed per weight unit of clay $(\mathrm{mg} / \mathrm{g}), C_{\mathrm{e}}$ is the equilibrium concentration of $\mathrm{Pb}(\mathrm{II})$ in solution after adsorption $\left(\mathrm{mg} \mathrm{L}^{-1}\right), X_{\max }$ and $b$ are the Langmuir coefficients. $X_{\max }$ represents the maximum adsorption capacity $\left(\mathrm{mg} \mathrm{g}^{-1}\right)$ and $b$ is an empirical Langmuir constant $\left(\mathrm{L} \mathrm{mg}^{-1}\right)$. According to equation (3), the Langmuir coefficients $\left(X_{\max }\right.$ and $b$ ) can be calculated from the plot of $C_{e} / q e$ as a function of $C_{e}$. The slope of the straight line obtained is equal to $1 / X_{\max }$ and the intercept is $1 /\left(X_{\max } b\right)$. Figure 10 shows good linear Langmuir behaviour for ArgB, K-Mako and K-Mako-APTES samples, confirming that this model describes adequately the adsorption.
From the values of $C_{0}$ and $b$ the separation factor $R_{L}$ was determined according to:

$$
R_{L}=1 /\left(1+b C_{0}\right)
$$

The data are reported in Table 2 for an initial $\mathrm{Pb}(\mathrm{II})$ concentration $C_{0}=5 \mathrm{mg} \mathrm{L}^{-1}$. All the $R_{L}$ values indicate that the isotherms are irreversible and the adsorption of $\mathrm{Pb}(\mathrm{II})$ on the clays from Mako is a favourable process to remove the metal from contaminated solutions (Erdemoglu et al., 2004). Interestingly, the maximum amount of $\mathrm{Pb}$ (II) uptake $\left(X_{\max }\right)$ is approximately three times higher for the organically modified clay K-Mako-APTES $\left(3.02 \mathrm{mg} \mathrm{g}^{-1}\right)$ compared to the raw clay sample $\left(0.99 \mathrm{mg} \mathrm{g}^{-1}\right)$. However the modified kaolinite adsorption capacity is still low in comparison with other materials such as activated carbon $\left(21.80 \mathrm{mg} \mathrm{g}^{-1}\right.$ at $\left.\mathrm{pH}=6, T=303 \mathrm{~K}\right)$ and GMZ bentonite $\left(23.83 \mathrm{mg} \mathrm{g}^{-1}\right.$ at $\mathrm{pH}=5.2, T=$ 293 K) (Rao et al., 2009; Wang et al., 2009).

TABLE 2. Langmuir parameters $\left(X_{\max }, b\right)$ and $R_{L}$ values determined from Fig. 10 and the equations given in the text.

\begin{tabular}{lcccc}
\hline Clay sample & $X_{\max }(\mathrm{mg} / \mathrm{g})$ & $b(\mathrm{~L} / \mathrm{mg})$ & Correlation $(\%)$ & $R_{L}$ \\
\hline ArgB & 0.99 & 23.16 & 0.99 & 0.88 \\
K-Mako & 1.46 & 12.62 & 0.99 & 0.01 \\
K-Mako-APTES & 3.02 & 16.35 & 0.99 & 0.01 \\
\hline
\end{tabular}




\section{CONCLUSIONS}

The raw clay material from the Mako area, Senegal, is essentially composed of kaolinite with minor quartz and traces of illite and goethite as was proved by XRD, SEM-EDS FTIR and TG-DTG analyses. Organic hybrid material was prepared from the clay fraction of this clay following grafting with the organo-silane reagent APTES. The initial clay fraction and new organo-clay hybrid materials have been used as adsorbents for the removal of $\mathrm{Pb}$ (II) from aqueous solutions. Langmuir isotherms were used to model the adsorption of $\mathrm{Pb}$ (II) ions on clays at equilibrium. The maximum amount of $\mathrm{Pb}$ (II) uptake at room temperature $\left(X_{\max }\right)$ was $0.99 \mathrm{mg} \mathrm{g}^{-1}$ for the raw clay $(\operatorname{ArgB}), 1.46 \mathrm{mg} \mathrm{g}^{-1}$ for its clay fraction and $3.02 \mathrm{mg} \mathrm{g}^{-1}$ for the organically modified clay (K-Mako-APTES), i.e. three times greater than the raw clay. Adsorption reaches a maximum at room temperature after about $30 \mathrm{~min}$ for an initial $\mathrm{Pb}$ (II) concentration of $10 \mathrm{mg} \mathrm{L}^{-1}$.

The clay material extracted from the Mako sample might be chemically functional and have applications as a heavy metal absorbent. Without reaching the adsorption performance of other clays such as bentonites, this chemically modified natural kaolinite material represents an interesting way of valorization of a natural and low cost clay, since its properties might further be optimized. Although economic criteria were not taken into account in this study, chemical modifications could be used to produce new adsorbents for the treatment of wastewater containing toxic heavy metals since this clay is abundant and cheap in this area of Senegal.

\section{ACKNOWLEDGMENTS}

Pr Cheikh A.K. Diop thanks the "Agence Universitaire de la Francophonie - AUF" for financial support.

\section{REFERENCES}

Barruseau J.P., Duvail C., Nehlig P., Roger J. \& Serrano O. (2009) Notice explicative de la carte géologique du bassin sédimentaire du Sénégal. Direction des Mines du Sénégal.

Beall G.W. (2003) The use of organo-clays in water treatment. Applied Clay Science, 24, 11-20.

Bouna L., Rhouta B., Amjoud M., Jada A., Maury F., Daoudi, L. \& Senocq F. (2010) Correlation between eletrokinetic mobility and ionic dyes adsorption of
Moroccan stevensite. Applied Clay Science, $\mathbf{4 8}$, 527-530.

Bouna L., Rhouta B., Amjoud M., Maury F., Lafont M.C., Jada A., Senocq F. \& Daoudi L. (2011) Synthesis, characterization and photocatalytic activity of $\mathrm{TiO}_{2}$ supported natural palygorskite microfibers. Applied Clay Science, 52, 301-311.

Celis R., Hermosin M.C. \& Cornejo J. (2000) Heavy metal adsorption by functionalized clays. Environmental Science and Technology, 34, 4593-4599.

Chi M. \& Eggleton R.A. (1999) Cation exchange capacity of kaolinite. Clays and Clay Minerals, 47, 174-180.

de Faria E.H., Ciuffi K.J., Nassar E.J., Vicente M.A., Trujillano R. \& Calefi P.S. (2010) Novel reactive amino-compound: Tris(hydroxymethyl)aminomethane covalently grafted on kaolinite. Applied Clay Science, 48, 516-521.

Dennis H.R., Hunter D.L., Chang D., Kim S., White J.L., Cho J.W. \& Paul D.R. (2001) Effect of melt processing conditions on the extent of exfoliation in organo-clay-based nanocomposites. Polymer, 42, 9513-9522.

Do D.D. (1998) Adsorption Analysis: Equilibria and Kinetics. Imperial College Press, London.

Erdemoglu M., Erdemoglu S., Sayilkan F., Akarsu M., Sener S. \& Sayilkan H. (2004) Organo-functional modified pyrophyllite: preparation, characterization and $\mathrm{Pb}(\mathrm{II})$ ion adsorption property. Applied Clay Science, 27, 41-52.

Farmer V.C. (1974) The Infrared Spectra of Minerals. Monograph 4, pp 331-363. Mineralogical Society, London.

Farmer V.C. \& Russell J.D. (1964) The infrared spectra of layer silicates. Spectrochimica Acta, 20, $1149-1173$.

Franco F., Pérez-Maqueda L.A. \& Pérez-Rodríguez J.L. (2004) The effect of ultrasound on the particle size and structural disorder of a well-ordered kaolinite. Journal of Colloid and Interface Science, 274, $107-117$.

Frost R.L., Kristof J., Paroz G.N. \& Kloprogge J.T. (1998) Molecular structure of dimethyl sulfoxide intercalated kaolinites. Journal of Physical Chemistry B, 102, 8519-8532.

Gómez-Romero P. \& Sanchez C. (2004) Functional Hybrid Materials. Wiley-VCH, Weinheim.

Grim R.E. (1953) Clay Mineralogy. McGraw-Hill Book Co., Inc., New York.

Groisman L., Rav-Acha C., Gerstl Z. \& Mingelgrin U. (2004) Sorption of organic compounds of varying hydrophobicities from water and industrial wastewater by long- and short-chain organo-clays. Applied Clay Science. 24, 159-166.

Gupta S.S. \& Bhattacharyya K.G. (2008) Immobilization of $\mathrm{Pb}(\mathrm{II}), \mathrm{Cd}(\mathrm{II})$ and $\mathrm{Ni}(\mathrm{II})$ ions on 
kaolinite and montmorillonite. Journal of Environmental Management, 87, 46-58.

Harvey C.C. \& Murray H.H. (1997) Industrial clays in the 21st century: a perspective of exploration, technology and utilization. Applied Clay Science, 11, 285-310

He H.P., Duchet J., Galy J. \& Gerard J.F. (2005) Grafting of swelling clay materials with 3-aminopropyltriethoxysilane. Journal of Colloid and Interface Science, 288, 171-176.

Holtzapffel T. (1985) Les minéraux argileux: préparation, analyse diffractométrique et détermination. Société géologique du nord, 12, 1-135.

Huang P. \& Fuerstenau D.W. (2001) The effect of the adsorption of lead and cadmium ions on the interfacial behavior of quartz and talc. Colloids and Surfaces A. Physiochemical and Engineering Aspects, 177, 147-156.

Ikhsan J., Johnson B.B. \& Wells J.D. (1999) A comparative study of the adsorption of transition metals on kaolinite. Journal of Colloid and Interface Science, 217, 403- 410.

Jiang M., Wang Q., Jin X. \& Chen Z. (2009) Removal of $\mathrm{Pb}$ (II) from aqueous solution using modified and unmodified kaolinite clay. Journal of Hazardous Materials, 170, $332-339$.

Lagadic I.L., Mitchell M.K., Payne B.D. (2001) Highly effective adsorption of heavy metal ions by a thiolfunctionalized magnesium phyllosilicate clay. Environmental Science and Technology, 35, 984-990.

Ledoux R.L. \& White J.L. (1964) Infrared study of selective deuteration of kaolinite and halloysite at room temperature. Science, 145, 47-49.

Letaief S. \& Detellier C. (2008) Interlayer grafting of glycidol (2,3-epoxy-1-propanol) on kaolinite. Canadian Journal of Chemistry, 86, 1-6.

Lothenbach B., Furrer G. \& Schulin R. (1997) Immobilization of heavy metals by polynuclear aluminium and montmorillonite compounds. Environmental Science and Technology, 31, $1452-1462$.

Malakul P., Srinivasan K.R. \& Wang H.Y. (1998) Metal adsorption and desorption characteristics of surfactant modified clay complexes. Industrial and Engineering Chemistry Research, 37, 4296-4301.

Mbaye A., Diop C.A.K., Rhouta B., Brendle J., Senocq F., Maury F. \& Diallo D.P. (2012) Mineralogical and physico-chemical characterizations of clay from Keur Saër (Senegal). Clay Minerals, 47, 499-511.

Mercier L. \& Detellier C. (1995) Preparation, characterization and applications as heavy metals sorbents of covalently grafted thiol functionalities on the interlamelar surface of montmorillonite. Environmental Science and Technology, 29, 1318-1323.

Murray H.H. (2000) Traditional and New Applications for Kaolin, Smectite, and Palygorskite: a General
Overview. Applied Clay Science, 17, 207-221.

Nakagaki S., Benedito F.L. \& Wypych F. (2004) Anionic iron(III) porphyrin immobilized on silanized kaolinite as catalyst for oxidation reactions. Journal of Molecular Catalysis A: Chemical, 217, 121-131.

Oyanedel-Craver V.A. \& Smith J.A. (2006) Effect of quaternary ammonium cation loading and $\mathrm{pH}$ on heavy metal sorption to $\mathrm{Ca}$ bentonite and two organobentonites. Journal of Hazardous Materials, B137, 1102-1114.

Paul D. R. \& Robeson L.M. (2008) Polymer nanotechnology: Nanocomposites. Polymer, 49, 3187-3204.

Pagenkopf G.K. (1978) Introduction to Natural Water Chemistry. Marcel Dekker Inc., New York.

Petit S. \& Decarreau A. (1990) Hydrothermal $\left(200^{\circ} \mathrm{C}\right)$ synthesis and crystal chemistry of iron-rich kaolinites. Clay Minerals, 25, 181-196.

Petit S., Decarreau A. Mosser C., Ehret G. \& Grauby O. (1995) Hydrothermal synthesis $\left(250^{\circ} \mathrm{C}\right)$ of copper substituted kaolinites. Clay Minerals, 43, 482-494.

Rao M.M., Ramana D.K., Seshaiah K., Wang C. \& Chien S.W.C. (2009) Removal of some metal ions by activated carbon prepared from Phaseolus aureus hulls. Journal of Hazardous Materials, 166, 1006-1013.

Saikia N.J., Bharali D.J., Sengupta P., Bordoloi D., Goswamee R.L., Saskia P.C. \& Borthakur P.C. (2003) Characterization, beneficiation and utilization of a kaolinite clay from Assam, India. Applied Clay Science, 24, 93-103.

Sari A., Tuzen M., Citak D. \& Soylak M. (2007) Equilibrium, kinetic and thermodynamic studies of adsorption of $\mathrm{Pb}$ (II) from aqueous solution onto Turkish kaolinite clay. Journal of Hazardous Materials, 149, 283-291.

Sarr D., Fall M., Ngom P.M. \& Ndiaye M. (2011) Mechanical Behaviour of Pillow Lavas in Mako Supergroup: Case of South Mako Hill. International Journal of Geosciences, 4, 640-647.

Shanmugharaj A.M., Rhee K.Y. \& Ryu S.H. (2006) Influence of dispersing medium on grafting of aminopropyltriethoxysilane in swelling clay materials. Journal of Colloid and Interface Science, 298, 854-859.

Shu-qin Y., Peng Y., Hong-ping H., Zong-hua Q., Qing Z., Jian-xi Z. \& Dong L. (2012) Effect of reaction temperature on grafting of $\gamma$-aminopropyltriethoxysilane (APTES) onto kaolinite. Applied Clay Science, 62-63, 8-14.

Srivasta P., Singh B. \& Angove M. (2005) Competitive adsorption behaviour of heavy metals on kaolinite, Journal of Colloid and Interface Science, 290, $28-38$.

Stathi P., Litina K., Gournis D., Giannopoulos T.S. \& Deligiannakis Y. (2007) Physicochemical study of novel organo-clays as heavy metal ion adsorbents for environmental remediation. Journal of Colloid and 
Interface Science, 316, 298-309.

Theng B.K.G. (1974) The Chemistry of Clay Organic Reactions. Adam Hilger, London.

Tonlé I.K., Diaco T., Ngameni E. \& Detellier C. (2007) Nanohybrid kaolinite-based materials obtained from the interlayer grafting of 3-aminopropyl triethoxysilane and their potential use as electrochemical sensors. Chemistry of Materials, 19, 6629-6636.

Tunney J.J. \& Detellier C. (1993) Interlamellar covalent grafting of organic units on kaolinite. Chemistry of Materials, 5, 747-748.

Tunney J.J. \& Detellier C. (1997) Interlamellar amino functionalization of kaolinite. Canadian Journal of Chemistry, 75, 1766-1772.

Van der Marel H.W. \& Beutelspacher S. (1976) Atlas of Infrared Spectroscopy of Clay Minerals and their Admixtures, 397 pp. Elsevier, Amsterdam.

Vansant E.F., Van der Voort P. \& Vrancken K.C. (1995) Characterization and Chemical Modification of the Silica Surface. Elsevier, Amsterdam.

Vizcayno C. Gutierrez R. M., Castello R., Rodriguez E. \& Guerrero C.E. (2010) Pozzolan obtained by mechanochemical and thermal treatments of kaolin.
Applied Clay Science, 49, 405-413.

Vengris T., Binkiene R. \& Sveikauskaite A. (2001) Nickel, copper, and zinc removal from wastewater by a modified clay sorbent. Applied Clay Science, 18, $183-190$.

Wang C., Shi H., Zhang P. \& Li Y. (2011) Synthesis and characterization of kaolinite/ $/ \mathrm{TiO}_{2}$ nano-photocatalysts. Applied Clay Science, 53, 646-649.

Wang S., Dong Y., He M., Chen L. \& Yu X. (2009) Characterization of GMZ bentonite and its application in the adsorption of $\mathrm{Pb}(\mathrm{II})$ from aqueous solutions. Applied Clay Science, 43, 164-171.

Wilson M.J. (1994) Clay Mineralogy: Spectroscopic and Chemical Determinative Methods, 18-60. Chapman and Hall, London, UK

Xi Y., Zhou Q., Frost R.L. \& He H., (2007) Thermal stability of octadecyltrimethyl ammonium bromide modified montmorillonite organo-clay. Journal of Colloid and Interface Science, 311, 347-353.

Yariv S. (2002) Introduction to organo-clay complexes and interactions. Pp 39-112 in: Organo-clay complexes and interactions (S. Yariv \& H. Cross, editors). Marcel Dekker Inc., New York. 